\title{
Prognostic value of flow cytometry in surgically treated primary gastric lymphoma
}

\author{
F. Fernández, J. C. Rodríguez-Sanjuán', M. Mayorga, J. Llorca², R. A. García', S. Trugeda' , F. de la Torre ${ }^{1}$ \\ and M. Gómez-Fleitas ${ }^{1}$
}

Departments of Pathology, 'General Surgery II, and ${ }^{2}$ Preventive Medicine and Public Health. University Hospital Marqués de Valdecilla. University of Cantabria. Santander, Spain

\begin{abstract}
Aim: to investigate whether flow cytometry could help to define the optimal therapeutic strategy of primary gastric lymphomas.

Material and method: retrospective study of 46 patients having primary gastric lymphoma -according to Dawson criteria- in Ann Arbor stage $I_{E}$ and $I_{E}$, who were surgically treated. From selected paraffin-embedded tissue blocks of the tumor, DNA content was studied by flow cytometry (FC). Other pathological tumor features were analysed by hematoxiline-eosine and Giemsa stains as well as immunohistochemical study; any possible influence on postoperative survival was investigated through statistical analysis.

Results: the DNA ploidy pattern was diploid in 40 cases (87\%) and aneuploid (hyperdiploid) in 6 (13\%). Postoperative survival probability (PSP) was $62.7 \%$ at 5 years. Statistical analysis showed significant prognostic value for Ann Arbor classification -with higher PSP for stage $I_{E}(p=0.009)$ - and FC parameters: diploid tumors had higher PSP than aneuploid tumors. Also tumors having S-phase ( $p=0.044)$ or G2-M phase values $(p=0.023)$ under the respective mean values had higher PSP. No influence on PSP was found for wall invasion, Helicobacter pylori infection, Isaacson's histologic type or resection margin involvement. No significant relationship was appreciated between Isaacson's histologic type and DNA ploidy patterns.

Conclusion: FC could be useful in assessing gastric lymphoma prognosis.
\end{abstract}

Key words: Stomach lymphoma. Flow cytometry.

Fernández F, Rodríguez-Sanjuán JC, Mayorga M, Llorca J, García RA, Trugeda S, de la Torre F, Gómez-Fleitas M. Prognostic value of flow cytometry in surgically treated primary gastric lymphoma. Rev Esp Enferm Dig 2006; 98: 817-827.

Recibido: 21-03-06.

Aceptado: 04-07-06.

Correspondencia: Juan C. Rodríguez-Sanjuán. Servicio de Cirugía General y Aparato Digestivo II. Hospital Universitario Marqués de Valdecilla. 39008 Santander. Fax: 942202 726. e-mail: cgdrsj@humv.es

\section{INTRODUCTION}

Gastric lymphoma is not a common tumor, with an incidence of 0.7-0.8 cases per 100,000 inhabitants in Western Europe (1). There is considerable controversy concerning gastric lymphoma treatment since there are several therapeutic options. Surgical resection, the classical treatment associated with good results, is increasingly being replaced by chemotherapy $(2,3)$, also showing good results but lacking long-term follow-up. Its pathogenesis has been associated with Helicobacter pylori $(H$. pylori) infection and thus these patients have also been exclusively treated with $H$. pylori eradication therapy, with complete remission in high percentages $(62-91,6 \%)$ $(4,5)$. Although monoclonality persistence has been reported in cases with complete histological remission, it has not a clear prognostic significance and long-term relapse rates are very low (5).

The assessment of prognostic factors could help to define a therapeutic strategy. Among these factors are the clinical stage, high-grade histologic type, serosal involvement, or proliferating cell nuclear antigen (PCNA) expression (4-11). Flow cytometry (FC) is a quantitative method of DNA content assessment. In most malignancies an abnormal DNA content -aneuploidy- has been found, and frequently it has been associated with an adverse prognosis: breast, urinary bladder, uterine cervix, ovary, colo-rectal and non-small cell lung tumors (12). In systemic non-Hodgkin lymphomas, there is no agreement concerning the prognostic value of FC (13-17). The published studies focusing on primary gastric lymphomas are scanty and also, the results concerning FC prognostic value are contradictory $(11,12,18-20)$.

The main aim of this study is to analyse the possible prognostic value of FC by correlating it with postoperative survival. As a secondary aim, we investigate the relationship of FC with other conventional histologic factors. 


\section{METHODS}

This is a retrospective study of 46 patients with primary gastric lymphoma defined according to Dawson's criteria (21) diagnosed and treated between 1974 and 1999. There were 23 women and 23 men with ranging 28-85 years (mean 64.1).

The first 14 patients of the series -all of them from 1974 to 1984 - were diagnosed by radiological imaging as having a "gastric tumor" and then operated on; a lymphoma was confirmed in the surgical specimen in all. The remaining 32 patients were diagnosed by gastroscopy and biopsy. Some of these cases were included I other previously reported series (22). In one patient AIDS was also diagnosed. This case has previously been published (23). Preoperative staging was performed by physical exam, peripheral blood study, bone marrow biopsy, chest X-ray and abdominal-thoracic computed tomography in patients treated after 1984. Patients with distant organ or lymph node involvement other than regional gastric nodes were excluded for surgery, which was the treatment of choice in our hospital protocol by the years when the patients were managed. Postoperative staging was performed according to the Ann Arbor classification (24). Thirty cases (65.2\%) were in stage IE -tumor limited to the gastric wall without positive lymph nodes; 16 cases (34.8\%) were in stage IIEtumor with positive lymph nodes.

Partial gastrectomy was performed in 36 patients (78.3\%) and total in $10(21.7 \%)$, according to whether the distance was greater or less than $5 \mathrm{~cm}$ to the cardia. Splenectomy was associated in 5 cases because of tumor proximity but without direct invasion. In 10 cases (21.7\%) microscopic margin involvement was found. Five of them received additive chemotherapy or radiotherapy. The remainder did not receive additive therapy for several reasons: three because they were considered unfit due to age or associated conditions and two refused further therapy. In the postoperative period -until hospital discharge- 4 patients died $(8.7 \%)$. Non-fatal complications were present in 5 patients $(10.9 \%)$. In 18 patients additive chemotherapy, consisting of cyclophosphamide, doxorubicin, vincristine and prednisone - $\mathrm{CHOP}-$ was administered and radiotherapy, in 3.

Paraffin-embedded blocks of the surgical specimen were revised. Studies with hematoxiline-eosine and Giemsa stains as well as immunohistochemical study were performed. The latter was done with the soluble complex alkaline phophatase-antiphosphatase (Biomeda Corp., Foster City CA, USA). A prediluted panel (all from Cormedica, Spain) was used, the common leukocyte antigen CD 45 being a marker for lymphocyte cells, L26 a marker for B phenotypic lymphocytes and UHCL1 a marker for $\mathrm{T}$ phenotypic lymphocytes.

Tumors were classified according to Isaacson's classification (25). Other histological features were studied by means of optic microscopy: after Giemsa stain $H$. pylori presence was observed and after haematoxylin-eosin margin involvement and wall invasion -partial versus total- were analysed. Since the differentiation zone where both normal and reactive lymphocytes are together is sometimes difficult to separate, the invasion level could not be precisely assessed in 3 cases.

The DNA content of the tumor was assessed by FC. Nuclear suspension from selected paraffin-embedded tissue blocks of the tumor was prepared using the method described by Hedley et al. (26) with certain modifications (27). Fifty-micron sections were cut on a rotatory microtome and placed into $10 \mathrm{ml}$ glass centrifuge tubes. The sections were deparaffinized in xylene and rehydrated in 100 , 95, 70 and 50\% ethanol at room temperature. The tissue was washed twice in distilled water and digested with $2 \mathrm{ml}$ of $0.1 \%$ protease (Sigma, Spain), in phosphate-buffered saline (PBS), $\mathrm{pH}$ 7.4. The tubes were placed in a waterbath at $37{ }^{\circ} \mathrm{C}$ for approximately 90 minutes, with intermittent vortex mixing. This solution was filtered through a 50-micron nylon mesh, centrifuged and stained with propidium iodide using the method described by Vindelov et al. (28). Ten thousand cells were analysed with a Becton Dickinson FACS analyser. The DNA index, G0/G1, S and G2/M phase fractions, and coefficient of variation (CV) for the G0/G1 peak were calculated using software supplied by Becton Dickinson (RFIT model). Inflammatory and epithelial cells from the same specimen (normal host cells) served as a control. The percentage of tumor cells in the different phases of cell cycle was assessed: G0/G1, S and G2-mitosis phase. The DNA index was also assessed: the relationship between phase G0/G1 of tumor population and phase G0/G1 of normal diploid population. As a result, every case is included in one of the following clonal categories: diploid (0.95-1.1.0) and aneuploid, beyond those limits. The latter can be classified into hypodiploid (< 0.95), hyperdiploid (1.10-1.90), tetraploid (1.95-2.10) and hypertetraploid (> 2.10). The mean variation coefficient was 7.1 (1.6-10.5).

Statistical analysis was carried out using the $\mathrm{Chi}^{2}$ and Fisher's exact tests. The Kaplan-Meier and log rank tests were used for survival analysis, performed only in patients treated by gastrectomy without postoperative death and not lost to follow-up. Deaths by other causes different to gastric lymphoma were considered as censored. The parameters included in survival analysis were: DNA content (clonal category), Ann Arbor stage, level of wall invasion, Helicobacter pylori infection, Isaacson's histologic type, resection margin involvement, S-phase fraction and G2/M phase fraction. For the latter two parameters, groups were arbitrarily defined as higher and less than each mean value. Regarding multivariate analysis, a sample size with at least ten events for every variable in the model is usually recommended (29,30). As there are only five tumor-related deaths in our sample, we avoided estimating hazard ratios via Cox regression, included for the univariate case; despite the small number of events, there is no problem in applying the log-rank test (as we do) since type I error is inflated when the events:variables ratio is lower than 4 (31); in our work, this ratio is 5 . 


\section{RESULTS}

Forty-four tumors could be classified according to Isaacson's classification: 28 (63.6\%) low grade type B (LG), $15(34.1 \%)$ high grade type B (HG) and $1(2.3 \%)$ type T. Wall invasion could be assessed in 43 cases: 25 (58.1\%) total and $18(39.1 \%)$ partial. H. pylori was isolated in $28(62.2 \%)$ cases out of the 45 cases assessable. FC data are shown in table I. DNA ploidy pattern was diploid in 40 cases (87\%) and aneuploid (hyperdiploid) in $6(13 \%)$. The percentage of cells in each cell cycle phase was as follows: G0/G1: $83.59 \%$ (s.d.: 12.68); S: $12.68 \%$ (s.d.: 10.99); G2/M: $3.72 \%$ (s.d.: 2.42 ).

Three patients $(6.5 \%)$ suffered clinical relapse, at 3, 6 and 9 months after surgery. Postoperative survival probability (PSP) was $62.7 \%$ at 5 years. The statistical analysis is shown in table II. Significant prognostic value was found for Ann Arbor classification -stage $I_{E}$ having a

Table I. Flow cytometry data, histology and tumor stage

\begin{tabular}{|c|c|c|c|c|c|c|c|}
\hline Case & Histology & DNA Index & $\begin{array}{l}\text { DNA ploidy } \\
\text { pattern }\end{array}$ & G0/G1 & $S$ & $G 2 / M$ & Stage \\
\hline 1 & $\mathrm{HG}$ & 1.8 & Hyperdiploid & 58.3 & 36.2 & 5.6 & IE \\
\hline 2 & LG & 1.2 & Hyperdiploid & 70.8 & 23 & 6.2 & IE \\
\hline 3 & LG & 1.19 & Hyperdiploid & 61.7 & 35.1 & 3.2 & $\mathrm{IE}$ \\
\hline 4 & LG & 1.18 & Hyperdiploid & 55.5 & 39.8 & 4.7 & IIE \\
\hline 5 & $\mathrm{HG}$ & 1.16 & Hyperdiploid & 72.1 & 21.2 & 6.7 & IIE \\
\hline 6 & $H G$ & 1.12 & Hyperdiploid & 59.2 & 30.4 & 10.4 & $\mathrm{IE}$ \\
\hline 7 & LG & 1 & Diploid & 94.5 & 4.6 & 1 & IIE \\
\hline 8 & LG & 1 & Diploid & 94.3 & 3.7 & 2 & IIE \\
\hline 9 & $\mathrm{HG}$ & 1 & Diploid & 63 & 26.8 & 10.2 & IIE \\
\hline 10 & LG & 1 & Diploid & 95.6 & 2.6 & 1.8 & IIE \\
\hline 11 & LG & 1 & Diploid & 94.4 & 3.9 & 1.7 & IIE \\
\hline 12 & LG & 1 & Diploid & 80 & 17 & 3 & IIE \\
\hline 13 & $H G$ & 1 & Diploid & 73.8 & 25.1 & 1.1 & IIE \\
\hline 14 & $\mathrm{HG}$ & 1 & Diploid & 86.3 & 8.8 & 4.9 & IIE \\
\hline 15 & LG & 1 & Diploid & 84.3 & 10.8 & 4.9 & IIE \\
\hline 16 & * & 1 & Diploid & 81 & 13.6 & 5.3 & IIE \\
\hline 17 & $\mathrm{HG}$ & 1 & Diploid & 86.3 & 8.5 & 5.2 & IIE \\
\hline 18 & $\mathrm{HG}$ & 1 & Diploid & 57.4 & 33.8 & 8.8 & IIE \\
\hline 19 & LG & 1 & Diploid & 92.5 & 6.4 & 1.1 & IIE \\
\hline 20 & $\mathrm{HG}$ & 1 & Diploid & 88.5 & 5.6 & 5.9 & IIE \\
\hline 21 & $\mathrm{HG}$ & 1 & Diploid & 92.5 & 6.5 & 0.9 & $\mathrm{IE}$ \\
\hline 22 & $\mathrm{HG}$ & 1 & Diploid & 75.4 & 18.2 & 6.4 & IE \\
\hline 23 & $\mathrm{LG}$ & 1 & Diploid & 95.6 & 2.7 & 1.7 & $\mathrm{IE}$ \\
\hline 24 & LG & 1 & Diploid & 71.4 & 24.5 & 4.2 & IE \\
\hline 25 & LG & 1 & Diploid & 94.6 & 2.9 & 2.5 & $\mathrm{IE}$ \\
\hline 26 & $H G$ & 1 & Diploid & 75.9 & 19.2 & 4.9 & $\mathrm{IE}$ \\
\hline 27 & LG & 1 & Diploid & 93.2 & 5 & 1.8 & IE \\
\hline 28 & LG & 1 & Diploid & 96.6 & 1.1 & 2.2 & $\mathrm{IE}$ \\
\hline 29 & LG & 1 & Diploid & 96.9 & 1.9 & 1.2 & $\mathrm{IE}$ \\
\hline 30 & LG & 1 & Diploid & 91.4 & 4.6 & 4 & $\mathrm{IE}$ \\
\hline 31 & $L G$ & 1 & Diploid & 88.7 & 8.5 & 2.8 & $\mathrm{IE}$ \\
\hline 32 & LG & 1 & Diploid & 96.6 & 1.8 & 1.5 & $\mathrm{IE}$ \\
\hline 33 & $\mathrm{HG}$ & 1 & Diploid & 81.5 & 15.6 & 2.9 & $\mathrm{IE}$ \\
\hline 34 & $\mathrm{LG}$ & 1 & Diploid & 87 & 9.9 & 3.1 & IE \\
\hline 35 & LG & 1 & Diploid & 87.5 & 9.1 & 3.5 & $\mathrm{IE}$ \\
\hline 36 & $H G$ & 1 & Diploid & 60.7 & 31.4 & 7.8 & $\mathrm{IE}$ \\
\hline 37 & LG & 1 & Diploid & 89.7 & 8.8 & 1.5 & $\mathrm{IE}$ \\
\hline 38 & LG & 1 & Diploid & 91.2 & 6.7 & 2.1 & $\mathrm{IE}$ \\
\hline 39 & $L G$ & 1 & Diploid & 92.9 & 5.3 & 1.8 & $\mathrm{IE}$ \\
\hline 40 & $*$ & 1 & Diploid & 87.7 & 10.4 & 2 & $\mathrm{IE}$ \\
\hline 41 & LG & 1 & Diploid & 96.7 & 2 & 1.3 & IE \\
\hline 42 & $T$ & 1 & Diploid & 82.5 & 12.9 & 4.7 & $\mathrm{IE}$ \\
\hline 43 & $L G$ & 1 & Diploid & 95.2 & 3.3 & 1.5 & $\mathrm{IE}$ \\
\hline 44 & LG & 1 & Diploid & 95.5 & 1.8 & 2.7 & $\mathrm{IE}$ \\
\hline 45 & LG & 1 & Diploid & 92.7 & 2.1 & 5.2 & $\mathrm{IE}$ \\
\hline 46 & $\mathrm{HG}$ & 1 & Diploid & 86.1 & 10.5 & 3.4 & $\mathrm{IE}$ \\
\hline
\end{tabular}

HG: high-grade B lymphoma; LG: low-grade B lymphoma; T: T lymphoma; *: not assessable. 
Table II. Statistical analysis: influence on postoperative survival probability. Univariate analysis

\begin{tabular}{|c|c|c|c|c|c|}
\hline \multicolumn{2}{|c|}{ Factor } & Patients & 5-year survivors & 5-year survival & $p$ \\
\hline \multicolumn{2}{|c|}{ Overall } & 46 & 19 & 90.5 (73.3 96.8) & - \\
\hline Ann Arbor stage & $\begin{array}{l}\mathrm{I}_{\mathrm{E}} \\
\mathrm{I}_{\mathrm{E}}\end{array}$ & $\begin{array}{l}30 \\
16\end{array}$ & $\begin{array}{r}11 \\
8\end{array}$ & $\begin{array}{c}100 \\
70.7(33.789 .5)\end{array}$ & 0.009 \\
\hline Helicobacter pylori & $\begin{array}{l}\text { No } \\
\text { Yes }\end{array}$ & $\begin{array}{l}17 \\
28\end{array}$ & $\begin{array}{r}7 \\
11\end{array}$ & $\begin{array}{l}81.8(44.795 .1) \\
95.2(70.799 .3)\end{array}$ & 0.269 \\
\hline Resection margin & $\begin{array}{l}\text { Free } \\
\text { Involved }\end{array}$ & $\begin{array}{l}36 \\
10\end{array}$ & $\begin{array}{r}14 \\
5\end{array}$ & $\begin{array}{l}92.1(71.998 .0) \\
83.3(27.397 .5)\end{array}$ & 0.507 \\
\hline Isaacson's type & $\begin{array}{l}\text { Low-grade } \\
\text { High-grade }\end{array}$ & $\begin{array}{l}28 \\
15\end{array}$ & $\begin{array}{r}14 \\
5\end{array}$ & $\begin{array}{l}94.7(68.199 .2) \\
88.9(43.398 .4)\end{array}$ & 0.499 \\
\hline Wall invasion & $\begin{array}{l}\text { Partial } \\
\text { Total }\end{array}$ & $\begin{array}{l}25 \\
18\end{array}$ & $\begin{array}{r}11 \\
6\end{array}$ & $\begin{array}{c}100 \\
83.9(49.495 .7)\end{array}$ & 0.107 \\
\hline Clonal category & $\begin{array}{l}\text { Diploid } \\
\text { Hyperdiploid }\end{array}$ & $\begin{array}{c}40 \\
6\end{array}$ & $\begin{array}{r}15 \\
4\end{array}$ & $\begin{array}{l}96.3(76.599 .5) \\
60.0(12.688 .2)\end{array}$ & 0.009 \\
\hline Extent of gastrectomy & $\begin{array}{l}\text { Partial } \\
\text { Total }\end{array}$ & $\begin{array}{l}36 \\
10\end{array}$ & $\begin{array}{c}16 \\
3\end{array}$ & $\begin{array}{c}88.7(69.096 .2) \\
100\end{array}$ & 0.446 \\
\hline S-phase fraction & $\begin{array}{l}<12 \\
>12\end{array}$ & $\begin{array}{l}26 \\
20\end{array}$ & $\begin{array}{r}12 \\
7\end{array}$ & $\begin{array}{c}100 \\
78.6(47.392 .5)\end{array}$ & 0.044 \\
\hline G2/M phase fraction & $\begin{array}{l}<4 \\
>4\end{array}$ & $\begin{array}{l}27 \\
19\end{array}$ & $\begin{array}{r}12 \\
7\end{array}$ & $\begin{array}{c}100 \\
75.5(41.691 .4)\end{array}$ & 0.023 \\
\hline
\end{tabular}

higher PSP - and FC parameters: diploid tumors had higher PSP than aneuploid ones (Fig. 1) and tumors having S-phase or G2-M phase values under the mean values had higher PSP. No influence on PSP was found for wall invasion, Helicobacter pylori infection, Isaacson's histologic type or resection margin involvement.

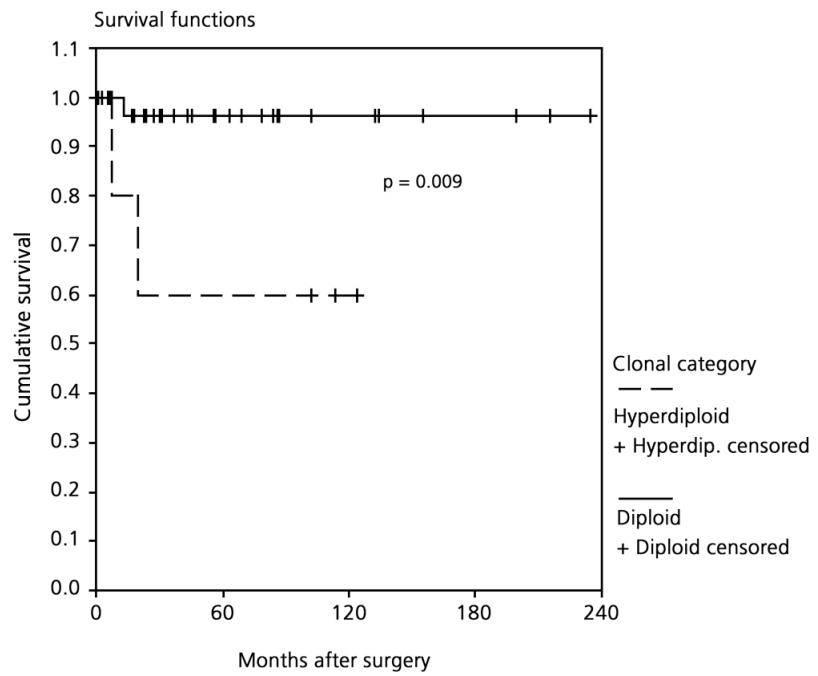

Fig. 1.- Postoperative survival probability according to DNA ploidy pattern.

Probabilidad de supervivencia postoperatoria según el patrón de ploidía tumoral.
On the other hand, although hyperdiploid tumors were commoner in the HG group (20\%) than in the LG group $(10.7 \%)$ no significant relationship was appreciated between histologic type and DNA ploidy patterns $\left(\mathrm{Chi}^{2}=\right.$ $0.7,1 \mathrm{df}, \mathrm{p}=0.3$ ). However, some differences were found between HG and LG tumors: HG tumors showed lower G0/G1 phase cell percentage $\left(\mathrm{Chi}^{2}=10.2,1 \mathrm{df}, \mathrm{p}=\right.$ $0.001)$, higher $\mathrm{S}$-phase cell percentage $\left(\mathrm{Chi}^{2}=10.2,1 \mathrm{df}\right.$, $\mathrm{p}=0.001)$ and higher $\mathrm{G} 2-\mathrm{M}$ phase cell percentage $\left(\mathrm{Chi}^{2}\right.$ $=11.0,1 \mathrm{df}, \mathrm{p}=0.001)$.

Significant differences between ploidy patterns were not found according to tumor stage $\left(\mathrm{Chi}^{2}=0.06,1 \mathrm{df}, \mathrm{p}=\right.$ $0.9)$ or wall invasion $\left(\mathrm{Chi}^{2}=1.2,1 \mathrm{df}, \mathrm{p}=0.27\right)$. Although Helicobacter pylori was commoner in diploid tumors $(67 \%)$ than in hyperdiploid tumors $(33 \%)$, the differences were not significant $\left(\mathrm{Chi}^{2}=2.5,1 \mathrm{df}, \mathrm{p}=0.1\right)$.

Of note, patients having border involvement with no evidence of any other residual tumor did not show a poorer PSP than tumor-free border. Among them there were not significant differences in stage $\mathrm{II}_{\mathrm{E}}$ frequency, $\mathrm{HG}$ tumor proportion, clonal category or patients receiving postoperative chemotherapy. It is remarkable that all patients with involved margin but one are alive, although one had a pulmonary relapse after 20 months.

\section{DISCUSSION}

The prognostic information provided from tumor samples is important because it can help in defining the thera- 
peutic strategy. This is especially relevant dealing with stomach lymphoma since there are several therapeutic options: Helicobacter pylori eradication, chemotherapy, surgery or combination of several of them. FC is one of the techniques that could provide such prognostic information and our results support such a hypothesis: aneuploid tumors had a significantly lower long-term survival than diploid tumors; also, higher values of S-phase fraction and G2-M fraction are associated with a significantly lower long-term survival. We recognize this study has several limitations as the relatively small numbers, the retrospective nature and the fact that some cases were treated long time ago and with different therapeutic strategies. However, this work provides significant information to the assessment of the $\mathrm{FC}$ prognostic value in gastric lymphoma, because the existing reports are conflicting. In addition, no much information is to be expected from future studies since most of stomach lymphomas will not longer be operated on because the current conservative approach. Another possible limitation of this study could be the fact that samples were not fresh but paraffin-embedded. This concerns one author since the material is poorer in his experience (13). A good agreement has, however, been found between FC performed with cells prepared either with fresh samples or those paraffin-embedded (32). Also the small number of tumorrelated deaths, which precluded multivariable analysis, as was previously explained in methods, could be a limitation.

Controversy exists concerning FC parameters prognostic value in lymphoma in general. It appears there is not enough evidence to show any independent prognostic value of aneuploidy according to Braylan's review (13), although other later works found significant influence $(14,15)$. S-phase prognostic value has also been reported (17).

The studies concerning FC in gastric lymphoma are scanty and involve small numbers: under 30 patients in all but the work by Aydin et al. (20) with 78. In some of them the only finding is S-phase prognostic value only in univariate but not in the multivariate analysis $(11,20)$. Joensuu et al. (18) found aneuploidy as a negative prognostic value but only in univariate analysis. The study by Bronzo et al. (12) only includes 4 cases of gastric lymphoma and thus conclusions cannot be drawn. The study by Okuda and Suzuki (19) is the only one which shows aneuploidy prognostic value confirmed by multivariate analysis, although only 24 gastric lymphomas are studied and they are not separated from lymphomas of other locations.

Concerning non-FC tumor features, we have not found any prognostic value for wall invasion nor histologic type by contrast with other works $(7,9,10)$ and even our previous analysis (6). The latter could be due to a longer follow-up and the inclusion of new patients. We only found prognostic value for the Ann Arbor classification. The lower proportion of G0/G1 cells and higher of S-phase cells in HG tumors means only a higher cell proliferation. As we published before (22), the lack of influence on prognosis of tumor margin involvement despite most of those patients not having received any additive treatment is surprising since higher long-term survival associated to excision with no residual tumor has been reported $(9,10,33)$.

The discussion about the best treatment of gastric lymphoma -surgery versus chemotherapy- to reach this objective is out of the scope of this work. From our current point of view, most of the cases would be treated by nonsurgical methods.

The finding of Helicobacter pylori in our cases is in the $62-96 \%$ reported range in LG tumors and $52-79 \%$ in HG tumors (4), which is one of the chief arguments in favour of its etiopathogenic relationship with MALT lymphoma.

In conclusion, we have found prognostic value for FC parameters. If these could be precisely assessed in endoscopic gastric biopsies, they could probably help in defining the therapeutic strategy of gastric lymphomas.

\section{REFERENCES}

1. Ullrich A, Fischbach W, Blettner M. Incidence of gastric B-cell lymphomas: a population-based study in Germany. Ann Oncol 2002; 13: $1120-27$

2. Maor MH, Velasquez SF, Fuller LM, Silvermintz KB. Stomach conservation in stages IE and IIE gastric non-Hodgkin's lymphoma. J Clin Oncol 1990; 8: 266-71.

3. Liu HT, Hsu C, Chen CL, Chiang IP, Chen LT, Chen YC, et al. Chemotherapy alone versus surgery followed by chemotherapy for stage I/IIE large-cell lymphoma of the stomach. Am J Hematol 2000; 64: $175-9$

4. Boot H, De Jong D. Gastric lymphoma: the revolution of the past decade. Scand J Gastroenterol 2002; 37 (Supl.) 236: 27-36.

5. Montalbán C, Santón A, Redondo C, García-Cosío M, Boixeda D, Vázquez-Sequeiros E, et al. Long-term persistence of molecular disease after histological remission in low-grade gastric MALT lymphoma treated with $\mathrm{H}$. pylori eradication. Lack of association with translocation $\mathrm{t}(11 ; 18)$ : a 10 -year updated follow-up of a prospective study. Ann Oncol 2005; 16: 1539-44.

6. Rodríguez-Sanjuán JC, Álvarez-Cañas C, Casado F, García-Castrillo L, Casanova D, Val-Bernal F, et al. Results and prognostic factors in stage Ie-IIe primary gastric lymphoma after gastrectomy. J Am Coll Surg 1999; 188: 296-303.

7. Taal LG, Boot H, van Heerde P, de Jong D, Hart AAM, Burgers JMV. Primary non-Hodgkin lymphoma of the stomach: endoscopic pattern and prognosis in low versus high grade malignancy in relation to the MALT concept. Gut 1996; 39: 556-61.

8. Nakamura S, Akazawa K, Yao T, Tsuneyoshi M. Primary gastric lymphoma. A clinicopathologic study of 233 cases with special reference to evaluation with the MIB-1 index. Cancer 1995; 76: 131324.

9. Kodera Y, Nakamura S, Yamamura Y, Shimizu Y, Torii A, Hirai T, et al. Primary gastric B-cell lymphoma: audit of 82 cases treated with surgery and classified according to the concept of mucosa-associated lymphoid tissue lymphoma. World J Surg 2000; 24: 857-62.

10. Radaszkiewicz T, DrHGosics B, Bauer P. Gastrointestinal malignant lymphomas of the mucosa-associated lymphoid tissue: factors relevant to prognosis. Gastroenterology 1992; 102: 1628-38.

11. Belessi CJ, Parasi AS, Manioudaki HS, Laoutaris NP, Legakis NC, Peros GT, et al. Prognostic impact of DNA ploidy pattern, S-phase 
fraction (SPF), and proliferating cell nuclear antigen (PCNA) in patients with primary gastric lymphoma. J Surg Oncol 2003; 82: 24755 .

12. Bronzo R, Heit P, Weismann G, Kahn E, McKinley M. Implications of flow cytometry in malignant conditions of the stomach. Am J Gastroenterol 1989; 84: 1065-8.

13. Braylan RC. Flow-cytometric DNA analysis in the diagnosis and prognosis of lymphoma. Am J Clin Pathol 1993; 99: 374-80.

14. Saikia UN, Dey P, Vohra H, Gupta SK. DNA flow cytometry of nonHodgkin's lymphomas: correlation with cytologic grade and clinical relapse. Diagn Cytopathl 2000; 22: 152-6.

15. Gómez Arbones J, Macià Virgili J, Campo Guerri E, Parra López R, Gallart Blanco MA, Panades Ciurana MJ. Valor diagnóstico y pronóstico del estudio por citometría de flujo del contenido en ADN y cinética celular de muestras parafinadas de linfoma. Sangre (Barc) 1994; 39: 423-8.

16. Morgan DR, Williamson JM, Quirke P, Clayden AD, Smith ME, O'Brien CJ, et al. DNA content and prognosis of non-Hodgkin's lymphoma. Br J Cancer 1986; 54: 643-9.

17. Holte Hsuo Z, Smeland EB, Kvaloy S, Langholm R, Stokke T. Prognostic value of lymphoma-specific S-phase fraction compared with that of other cell proliferation markers. Acta Oncol 1999; 38: 495503.

18. Joensuu K, Söderström KO, Klemi P, Eerola E. Nuclear DNA content and its prognostic value in lymphoma of the stomach. Cancer 1987; 60: 3042-8.

19. Okuda A, Suzuki H. Effects of DNA ploidy patterns on the survival of patients with primary gastrointestinal lymphoma. Surg Today 1996; 26: 586-90.

20. Aydin ZD, Barista I, Canpinar H, Sungur A, Tekuzman G. Gastric lymphomas in Turkey. Analysis of prognostic factors with special emphasis on flow cytometric DNA content. Cancer 2000; 89: 12-2.

21. Dawson IMP, Cornes JS, Morson BC. Primary malignant lymphoid tumours of the intestinal tract. Br J Surg 1961; 49: 80-9.

22. Rodríguez-Sanjuán JC, García RA, Trugeda S, de la Torre F, Llorca J, Gómez-Fleitas M. ¿Existen indicaciones actuales para la cirugía en el linfoma gástrico? Rev Esp Enferm Dig 2006; 98: 180-8.

23. Rodríguez-Sanjuán JC, Echevarría S, Álvarez-Cañas C, Naranjo A. Primary gastric lymphoma in an H.I.V.-Infected patient (Letter). J AIDS Hum Ret 1996; 13: 467-8.

24. Carbone PP, Kaplan HS, Musshoff K, Smithers DW, Tubiana M. Report of the committee on Hodgkin's disease staging classification. Cancer Res 1971; 31: 1860-1.

25. Isaacson PG, Spencer J, Wright DH. Classifying primary gut lymphomas. Lancet 1988; ii: 1148-9.

26. Hedley DW, Friedlander ML, Taylor IW, Rugg CA, Musgrove EA. Method for analysis of cellular DNA content of paraffin-embedded pathological material using flow cytometry. J Histochem Cytochem 1983; 31: 1333-5.

27. MacLeod CB, Repetti CF, Tsokos M. Enzymatic treatments of paraffin blocks for DNA flow cytometry. Mod Pathol 1992; 5: 569-74.

28. Vindelov LL, Christensen IJ, Nissen NI. A detergent-trypsin method for the preparation of nuclei for flow cytometric DNA analysis. Cytometry 1983; 3: 323-7.

29. Concato J, Peduzzi P, Holford TR, Feinstein AR. The importance of events per independent variable (EPV) in proportional hazards analysis: I. Background, goals and general strategy. J Clin Epidemiology 1995; 48: 1495-501.

30. Peduzzi P, Concato J, Feinstein AR, Holford TR. The importance of events per independent variable (EPV) in proportional hazards analysis: II. Accuracy and precision of regression estimates. J Clin Epidemiology 1995; 48: 1503-10.

31. Harrel F, Lee KL, Matchar DB, Reichert TA. Regression models for prognostic prediction: Advantages, problems and suggested solutions. Cancer Treatment Reports 1985; 69: 1071-7.

32. Camplejohn RS, Macartney JC. Comparison of DNA flow cytometry from fresh and paraffin embedded simples of non-Hodgkin's lymphoma. J Clin Pathol 1985; 38: 1096-9.

33. Ruskoné-Fourmestraux A, Aegerter P, Delmer A, Brousse N, Galian A, Rambaud JC, and the Groupe d'étude des lymphomes digestifs. Primary digestive tract lymphoma: a prospective multicentric study of 91 patients. Gastroenterology 1993; 105: 1662-71. 